\title{
THE EFFECT OF BIG FIVE PERSONALITY ON FEAR OF MISSING OUT
}

\author{
Inggrid Savitri $^{1}$, Awang Setiawan Wicaksono ${ }^{2}$, Chandrania Fastari ${ }^{3}$ \\ Psychology Faculty, Universitas Muhammadiyah Gresik
}

\section{Inggrid.sa23@gmail.com 1 , awangwicaksono.psi@umg.ac.id ${ }^{2}, \underline{\text { chandraniafastari@umg.ac.id }}$}

\begin{abstract}
This study aims to examine the influence of the Big Five Personality on Fear of Missing Out. Fear of missing out is the worry that individuals experience when other people experience impressive experiences in their absence, FOMO is characterized by the desire that the Big-Five Taxonomy does not aim to replace the existing system, but acts as an unifier because it can provide an explanation of the general personality system. In this study, the method used is a quantitative method with a population consisting of 284 students and the number of sample is 71 students of the Faculty of Psychology, University of Muhammadiyah Gresik. In this case the researchers used simple random sampling technique. The data analysis technique used multiple linear regression with a significant level of $5 \%$. The result iss obtained that the value of $r$ count $=0.453$ then Ho is rejected and $\mathrm{Ha}$ is accepted. The result of the coefficient ( $\mathrm{r} 2$ ) of $\mathrm{r}=0.453=0.205$, which indicates that the contribution of the Big-Five personality dimension with a fear of missing out is $20.5 \%$, while the rest is by other variables not examined. Based on the data analysis, it can be concluded that there is a simultaneous influence of Big Five personality on fear of missing out.
\end{abstract}

Keywords: Fear of Missing Out, Big Five Personality

\section{INTRODUCTION}

Technological developments in the 4.0 revolution era are closely related to the internet. The hallmark of this revolutionary era is the close relationship between humans and the internet or commonly referred to as the internet of things/internet of people (Hermann, et al; 2016). The internet itself is defined as a communication network that can make it easier for all users to connect to each other from various places using the internet protocol (IP) system. Roger Fidler mentions the terms coexistence and coevolution of human development (in Riyanto, 2016) that humans cannot be separated from technological developments, so technology in this era is considered a major need for some people.

According to a survey conducted by the Association of Indonesian Internet Service Providers (APJII), the number of internet users in Indonesia in 2018 was 171.17 million out of a total 264.16 million Indonesian population, or $64.8 \%$ of the entire population of Indonesia are internet users. active. This number increased by $10.12 \%$ from 2017 , the age range of the most internet users in Indonesia is from the age of 15-29 years. In research 
conducted by JWT Intelligence (2011), it was found that the younger generation aged 1833 years is the group that most admits to suffering from FOMO (72\%) when compared to other generations. Then followed by the adolescent age group (13-17 years) as much as $56 \%$.

With the increasing number of internet users, especially social media with high intensity, this will have an impact on users both physically and psychologically. In addition, the high intensity of internet use can be indicated as internet addiction which has negative impacts such as anxiety, interpersonal relationships, decreased physical and mental health, depression, and decreased performance (Yen et al, 2014:1602). Another result of a survey conducted by APJII states that $19.1 \%$ of internet users use the internet to access social media, this is also in accordance with the researcher's initial survey which showed 37 out of 56 respondents accessed social media when using the internet.

Przybylski (2013), someone who checks his social media repeatedly and looks for information even when he wakes up or drives is an individual who experiences FOMO. When an individual finds out that a colleague or other person is having a party without inviting him or her, or buying the things he wants, it causes anxiety (Abel et al., 2016:35). Przybylski (2013: 1844) states that individual demographics such as gender and age affect a person's FOMO level. Przybylski also suggests that Big-Five's personality has something to do with FOMO. Big Five personality is an approach that groups personality traits with factor analysis. Notable pioneers were Allport and Cattel. Big Five personality is used to determine the human personality which has 5 dimensions of traits. The five dimensions are extraversion, agreeableness, conscientiousness, neuroticism, openness to experiences.

Budysan., et al (2019:36), neuroticism is one of the dimensions in the Big-five that has a relationship with internet addiction. According to Tresnawati (2016:184), there is a positive correlation on the dimensions of agreeableness \& extraversion with FOMO. According to Ristia, et al (2018) stated that the dimensions of neuroticism \& conscientiousness have an influence on FOMO. In accordance with the background explanation above, with this, researchers are interested in knowing whether the big-five personality has an influence on FOMO.

\section{METHOD}

\section{Data source and sampling}

The subjects of this research are active students of the Faculty of Psychology, University of Muhammadiyah Gresik totaling 283 students aged 18-29 years which this age range is included in emerging adulthood, most researchers in the internet realm choose participants in emerging adulthood, on the condition that individuals who use social media for more than 8 hours per day. The total population that meets the criteria set by the researcher is 249 students. The determination of the number of samples was carried out using the Slovin technique according to Sugiyono (2011: 87).

The subjects in this study were selected using a probability sampling technique, where each subject in a population has an equal chance of being selected as a sample (Azwar, 2017: 
114). The type of sampling used is simple random sampling, starting with making a complete list of names or subject numbers that meet the characteristics (Azwar, 2017: 116).

\section{Measure}

In this study, the data collection method used was to spread the research scale to subjects who had been determined with certain criteria so that the data obtained were primary data. The type of scale used in this study is a Likert scale, where the subject is directed to choose one of several types of responses that have been provided. There are two scales that will be used in this study, namely the fear of missing out scale belonging to Przybylski et al (2013) and The Big-Five Personality Traits scale which is an adaptation of the Big-five Inventory. Provides 5 response options on the fear of missing out scale, namely $1=$ Doesn't Describe Me, 2 = Describes Me Little, 3 = Moderately Describes Me, $4=$ Describes Me and $5=$ Very Describes Me.

The independent variables in this study will be measured using the Big Five Inventory (BFI) scale, created by Oliver P. John and V. Benet-Martinez in 1998, there are 44 items on this scale. With the original Likert scale of 1-4 starting from Very Appropriate to Very Disagree. John \& Srivastava (1999) has tested the BFI scale which produces Cronbach's Alpha reliability of 0.83 . For the adaptation scale which has been translated into Indonesian, Ramdhani (2012) obtained the reliability of every aspect in the BFI, including extraversion (0.73), Agreeableness (0.76), Conscientiousness (0.78), Neuroticism (0.74), and Openness (0.79) with a total of 28 items.

\section{Analysis}

The data analysis technique used in this research is multiple linear regression analysis, which is a regression analysis technique with one dependent variable and several independent variables. Regression analysis is used to find out how the dependent variable can be predicted through independent variables or predictors individually/partial or jointly/simultaneously (Sugiyono, 2015: 154). Furthermore, the entire statistical analysis process used in this study used the IBM Statistical Program for Social Science (SPSS) computer program for windows version 25.0. If the significance value on the $\mathrm{F}$ test $<0.05$, then there is a joint influence between the independent variables on the dependent variable, and if the significance value of the t-test $<0.05$ then there is a partial effect of the independent variable on the dependent variable.

\section{RESULT}

Based on the calculation of the validity and reliability of the items in the Fear of Missing Out and Big-Five Personality variables that have been carried out, there were no items that fell out so that all items were used in data collection and data analysis. The results of the normality test showed that the data from the two variables were normally distributed, there was no multicollinearity, no heteroscedasticity problem and no autocorrelation problem. So 
the researchers conducted an analysis with multiple linear regression analysis method using the SPSS 25.0 for windows program.

The hypothesis proposed by the researcher is as follows:

$\mathrm{Ha}=$

- There is Big-Five Personality Effect on FOMO

- Extraversion has an effect on FOMO

- There is an effect of Agreeableness on FOMO

- There is an effect of Conscientiousness on FOMO

- There is an effect of Neuroticism on FOMO

- There is an effect of Openness to experience on FOMO

$\mathrm{H} 0=$

- No BigFive Personality effect on FOMO

- No Extraversion effect on FOMO

- There is no effect of Agreeableness on FOMO

- There is no effect of Conscientiousness on FOMO

- There is no effect of Neuroticism on FOMO

- There is no effect of Openness to experience on FOMO

If the significance value $<0.05$ means that there is an influence between Big-Five Personality and Fear Of Missing Out.

The model summary shows an $\mathrm{R}$ value of 0.453 . While the coefficient of determination ( $R$ Square) of 0.205 or $20.5 \%$ is the magnitude of the contribution of the influence of extraversion, agreeableness, conscientiousness, neuroticism and openness to experience on fear of missing out.

The calculated $F$ value is 3.399 with a significance ( $\mathrm{sig}$ ) of 0.009 . Based on the decision criteria above, it can be concluded that the effect of extraversion (x1), agreeableness (x2), conscientiousness (x3), neuroticism (x4), and openness to experience (x5) on fear of missing out is significant because the Sig value of 0.009 is smaller than $0.05(0.009<0.05)$. The $\mathrm{F}$ test is used to test the effect of the independent variables together on the dependent variable, by determining the null hypothesis and the alternative hypothesis, namely:

$\mathrm{H} 0=0$

This means that extraversion, agreeableness, conscientiousness, neuroticism, and openness to experience together have no effect on FOMO.

$\mathrm{Ha} \neq 0$

This means that extraversion, agreeableness, conscientiousness, neuroticism, and openness to experience together have an effect on FOMO.

Decision making if the significance $>0.05 \mathrm{H} 0$ is accepted and if the significance is 0.05 then $\mathrm{H} 0$ is rejected. It is known from the table above that the significance value of 0.009 is smaller than 0.05 so that the null hypothesis is rejected, the conclusion is that extraversion, agreeableness, conscientiousness, neuroticism, and openness to experience together affect FOMO.

Furthermore, a t-test was conducted to test the effect of the independent variable partially on the dependent variable. Based on the hypothesis that has been determined with the decision-making criteria if the significance $>0.05$ then $\mathrm{HO}$ is accepted and $\mathrm{Ha}$ is rejected 
and vice versa if the significance is $<0.05$ then $\mathrm{HO}$ is rejected and $\mathrm{Ha}$ is accepted. The data obtained that the significance value of extraversion is $0.095>0.05$, agreeableness is $0.756>$ 0.05 , conscientiousness is $0.198>0.05$, neuroticism is $0.012<0.05$ and openness to experience is $0.112>0.05$. So it can be concluded that those who have an influence on FOMO are individuals with neuroticism personality, while the personality of extraversion, agreeableness, conscientiousness and openness to experience have no effect on fear of missing out.

\section{DISCUSSION}

Based on the results of the regression analysis, it was also stated that there was a significant effect of the five Big Five independent variables on the dependent variable FOMO of $20.5 \%$, and the rest were other factors not examined. A calculated F value of 3.399 is also obtained with a significance of 0.009 which is smaller than 0.05 which can be concluded that extraversion, agreeableness, conscientiousness, neuroticism and openness to experience simultaneously affect FOMO. After doing the F test, followed by the test to partially test the effect of the independent variable on the dependent variable, which resulted in data, namely the significance value of extraversion was $0.095>0.05$, agreeableness was $0.756>0.05$, conscientiousness was $0.198>0,05$, neuroticism is $0.012<0.05$ and openness to experience is $0.112>0.05$. So it can be concluded that those who have an influence on FOMO are individuals with neuroticism personality, while the personality of extraversion, agreeableness, conscientiousness and openness to experience have no effect on fear of missing out.

This is supported by previous research by Stead (2017:4) which has highlighted the relationship between anxiety and neuroticism, both of which are included in anxiety disorders, considering that FOMO is related to anxiety. Correa (2010) mentions that it is possible that neuroticism is not the only one that can explain the relationship between FOMO and Big-Five. Another study that supports the results of this study is a study by Dmitri in 2020 where the results of his research show that of the five Big Five dimensions, only the neuroticism dimension has a significant effect on Fear of Missing Out (FOMO).

\section{CONCLUSION}

Based on the results of the analysis of research data using Multiple Linear Regression Test, it can be concluded that the results show that the significance value of agreeableness personality is $0.012<0.05$ with the regression line equation $Y^{\prime}=-1.433+0.644 \mathrm{X} 1+0.090 \mathrm{X} 2$ $0.455 \times 3+0.880 \mathrm{X} 4+0.476 \times 5$, to predict the value of fear of missing out based on personality predictors of extraversion, agreeableness, conscientiousness, neuroticism and openness to experience. It can be concluded that $\mathrm{H} 0$ is rejected and $\mathrm{Ha}$ is accepted as a predictor of neuroticism, while $\mathrm{H} 0$ is accepted and $\mathrm{Ha}$ is rejected for the dimensions of Agreeableness, Extraversion, Conscientiousness and Openess to Experience because it has a significance value of more than 0.05 . So that the multiple regression analysis shows that there is a significant effect of the independent variable neuroticism on the dependent variable fear of missing out. The results showed that the Rsquare value of $0.205 \%$ or $20.5 \%$ of the Big-Five personality affected the fear of missing out. The results of the categorization 
of subjects according to the Big-five personality showed that 13 students had extraversion personality with a percentage of $18 \%, 36$ students with agreeableness personality with a percentage of $50 \%, 7$ students with conscientiousness personality with a percentage of $10 \%$, 0 students with neuroticism with a percentage of $0 \%$ and 16 students have an openness to experience personality with a percentage of $22 \%$.

\section{REFERENCES}

Abel, J. P., Buff, C. L., \& Burr, S. A. (2016). Social Media and the Fear of Missing Out:Scale Development and Assessment. Journal of Business \& Economics Research, 34-44.

Adams, S. K., Williford, D. N., Vaccaro, A., Kisler, T. S., Francis, A., \& Newman, B. (2016). The young and the restless: Socializing trumps sleep, fear of missing out, and technological distractions in first-year college students. International Journal of Adolescence and Youth, 1-12.

Alt, D., \& Boniel-Nissim, M. (2018). Parent-Adolescent Communication and Problematic Internet Use: The Mediating Role of Fear of Missing Out (FoMO). Journal of Family Issues, 1-19.

Alwisol. (2009). Psikologi Kepribadian. Malang.

Angesti, R., \& Oriza, I. D. (2018). Peran Fear of Missing Out (FOMO) Sebagai Mediator Antara Kepribadian dan Penggunaan Internet Bermasalah. Jurnal Muara.

Bestari, I. U., \& Widayat, I. W. (2018). Hubungan antara Fear of Missing Out dengan intensitas penggunaan jejaring sosial pada mahasiswa universitas airlangga. Jurnal psikologi pendidikan dan perkembangan, 19-29.

Blackwell, D., Leaman, C., Tramposch, R., Osborne, C., \& Liss, M. (2017). Extraversion, neuroticism, attachment style and fear of misssing out as predictors of social media use and addiction. Personality and Individual Differences, 69-72.

Borca, G., Bina, M., Keller, P. S., Gilbert, L. R., \& Begotti, T. (2015). Internet use and developmental tasks: Adoescents point of view. Computers in Human Behavior, 49-58.

Budysan, T., \& Sidjaja, F. F. (2019). Hubungan antara tipe kepribadian Big Five dengan adiksi internet pada mahasiswa di Surabata. Jurnal Experientia, 31-41.

Can, G., \& Satici, S. A. (2019). Adaptation of fear of missing out scale (FoMOs): Turkish version validity and reliability study. Psicologia: Reflexao e Critica, 1-7.

Dhir, A., Yossatorn, Y., Kaur, P., \& Chen, S. (2018). Online social media fatigue and psychological weelebing--A study of compulsive use, fear of missing out, fatigue, anxiety and depression. International Journal of Information Management, 141-152.

Eggermont, S., \& Bulck, J. V. (2006). Nodding off or switching off? The use of popular media as a sleep aid in secondary-school children. J Paediatr Child Health, 428-433. 
Elhai, J. D., Levine, J. C., Dvorak, R. D., \& Hall, B. J. (2016). Fear of Missing Out, need for touch, anxiety and depression are related to problematic smartphone use. Computers in Human Behavior, 509-516.

Etindele Sosso, F. A., Nakamura, O., \& Nakamura, M. (2017). Evaluation of Combined Effects of Insomnia and Stress on Sleep Quality and Sleep Duration. Journal Of Neurology And Neuroscience, $1-5$.

Fathadhika, S., \& Afriani. (2018). Social Media Engagement sebagai medatir antara Fear of Missing Out dengan kecanduan media sosial pada remaja. Jurnal psikologi sains dan profesi, 208-215.

Feist, J., \& Gregory, F. J. (2008). Theories of Personality (Edisi Keenam). Yogyakarta: Pustaka Belajar.

Grohol, M. J. (2011, April 14). FOMO addiction: The Fear of Missing Out. Retrieved November 16, 2019, from PsychCentral: http://psychcentral.com/blog/archives/2011/04/14/fomo-addiction-the-fear-of-missingout

Hamburger, Y. A. (2002). Internet and personality. Computers in Human Behavior, 1-10.

Hermann M., P. T. (2016). Design principles for industrie 4.0 scenarios System Sciences (HICSS). 49th Hawaii International Conference, 3928-3937.

Hertz, P. R., Dawson, C. L., \& Cullen, T. A. (2016). Social media use and the Fear of Missing Out (FoMO) while studying abroad. Journal of Research on Technology in Education, 259-272.

Hirschman, E. C. (1992). The Consciousness of Addiction: Toward a General Theory of Compulsive Consumption. Journal of Consumer Research, 155-179.

Huebner, E. S. (1991). Initial Development of the Student's Life Satisfaction Scale.

Hurlock, E. B. (1980). Psikologi Perkembangan: Suatu Pendekatan Sepanjang Rentang Kehidupan. Jakarta: Erlangga.

John, O. P., \& Srivastava, S. (1999). The Big Five trait taxonomy: History, measurement and theoretical perspective. Handbook of Personality: Theory and Research, 102-138.

Kuss, D. J., Shortner, G. W., van Rooij, A. J., Mheen, D. v., \& Griffiths, M. D. (2014). The Internet addiction components model and personality: Establishing construct valifity via a normological network. Computers in Human Behavior, 312-321.

Lai, C., Altavilla, D., Ronconi, A., \& Aceto, P. (2016). Fear of missing out (FOMO) is associated with activation of the right middle temporal gyrus during inclusion social cue. Computers in Human Behavior, 516-521. 
Marshall, T. C., Lefringhausen, K., \& Ferenczi, N. (2015). The Big Five, self-esteem, and narcissism as predictors of the topics people write about in Facebook status upfdates. Personality and Individual Differences, 35-40.

McCrae, R. R., \& Costa,Jr, P. T. (1999). A Five-Factor theory of Personality. In L. Pervin, \& O. John, Handbook of Peronality: Theory and research (2nd ed) (pp. 139-153). New York: Guilford.

Meerkerk, G.-J., Eijnden, R. V., Vermulst, A., \& Garretsen, H. (2009). The Compulsive Internet Use Scale (CIUS): some psychometric properties. 1-6.

Milyavskaya, M., Saffran, M., Hope, N., \& Koestner, R. (2018). Fear of Missing Out: Prevalence, dynamics, and consepuences of experiencing FOMO. Motivation and emotion, 1-13.

Miranda. (2012, March). Fear of Missing Out (FOMO). Retrieved Agustus 2021, from JWT: http://www.jwtintelligence.com

Oberst, U., Wegmann, E., Stodt, B., Brand, M., \& Chamarro, A. (2017). Negative consequences from heavy social networking in adolscecents: The mediating role of fear of missing out. Journal of Adolescence, 51-60.

Priyatno, D. (2016). Belajar Alat analisis Data dan Cara Pengolahannya dengan SPSS. Yogyakarta: Penerbit Gava Media.

Przybylski, A. K., Murayama, K., DeHaan, C. R., \& Gladwell, V. (2013). Motivational, emotional, and behavioral correlates of fear of missing out. Computers in Human Behavior, 1841-1848.

Robbins, S. P., Iskandarsyah, T., \& Pujaatmaka, H. (2001). Perilaku organisasi: konsep, kontroversi, aplikasi. Jakarta: Prenhallindo.

Saifuddin, A. (2007). Metode Penelitian Kuantitatif. Yogyakarta: Pustaka Pelajar.

Sianipar, N. A., \& Kaloeti, D. V. (2019). Hubungan antara regulasi diri dengan Fear of Missing Out (FoMO) pada mahasiswa tahun pertama fakultas psikologi universitas diponegoro. Jurnal Empati, 136-143.

Stead, H., \& Bibby, P. A. (2017). Personality, Fear of Missing Out and Problematic Internet Use and Their Relationship to Subjective Well-Being. Computers in Human Behavior, $1-22$.

Stead, H., \& Bibby, P. A. (2017). Personality, Fer of Missing Out and Problematic Internet Use and their Relationship to Subjective Well-Being. Computers in Human Behavior, 534540.

Sugiyono. (2015). Metode Penelitian Kombinasi (Mix Methods). Bandung: Alfabeta. 
Syabani, S. N., \& Sofia, N. (2019). Fear of Missing Out Ditinjau dari Kepuasan Hidup Pada Remaja Pengguna Media Sosial. 16.

Tresnawati, F. R. (2016). hubungan antara The Big Five Personality Traits dengan Fear of Missing Out About Social Media pada mahasiswa. Jurnal ilmiah psikologi, 179-185.

Wibowo, D. S., \& Nurwindasari, R. (2019). Hubungan Intensitas Penggunaan Instagram Terhadap Regulasi Diri dan Fear of Missing Out. Prosiding Seminar Nasional \& Call Paper Psikologi Sosial 2019, 323-327.

Yen, C.-F., Chou, W.-J., Liu, T.-L., Yang, P., \& Hu, H.-F. (2014). The association of Internet addiction symptoms with anxiety, depression and. Comprehensive Psychiatry, 16011608 . 